\title{
MODEL KEMATANGAN NHS INFRASTRUCTURE (NIMMTM) UNTUK EVALUASI INFRASTRUKTUR TI PADA RUMAH SAKIT DI YOGYAKARTA
}

\author{
Danny Sebastian ${ }^{1}$ \\ sebastian.community@gmail.com
}

\author{
Benyamin $\mathrm{LS}^{2}$ \\ blsinaga@mail.uajy.ac \\ .id
}

\author{
F Sapty Rahayu ${ }^{3}$ \\ sapty@mail.uajy.ac.id
}

\begin{abstract}
IT infrastructure is an important for a company to achieve competitive advantages. All bussiness industry needs a good IT infrastructure to support their business, it also experienced by healthcare industry. However in Indonesia, there is no standarisation for IT infrastructure in hospital. The purpose of this research is to adapt NHS infrastructure maturity model $\left(N_{I M M}{ }^{T M}\right)$ based on Indonesian hospital environment, in this case RS XYZ. This research consist of 3 steps, preliminary study (1), maturity model adaptation (2), and maturity model validation (3). The adapted maturity model consist of 11 categories and 60 key capabilities. Each key capabilities has 5 perspectives, process perspective, organisation \& people perspective, technology perspective, IT security \& information governance perspective, and strategy alignment \& business value perspective. Each perspective has at least 1 KPI and total KPI of this adapted maturity model is 432 KPIs. The adapted maturity model can be used for IT infrastructure maturity evaluation and a guidelines for enhance IT infrastructure.
\end{abstract}

Keywords: NHS Infrastructure, NIMM ${ }^{\mathrm{TM}}$, IT Infrastructure maturity model, model kematangan, adaptasi model kematangan, health IT infrastructure.

\section{Pendahuluan}

Setiap perusahaan selalu berusaha memiliki Competitive advantages untuk memenangkan persaingan. Infrastruktur TI yang kuat merupakan salah satu hal yang memberikan dukungan terhadap pencapaian competitive advantages (IBM Institute). Penelitian kedua/lanjutan yang dilakukan oleh (IBM Institute) menemukan bahwa pembuatan infrastruktur TI yang sukses tidak hanya membutuhkan leading di teknologi, tetapi juga efektifitas dalam menyediakan IT services.

Selain itu, pentingnya infrastruktur TI juga didukung oleh adanya perubahan trend IT (big data, cloud, e-bisnis) yang membutuhkan investasi infrastruktur TI yang mahal pada tahun 2015 (Rossi, 2015; Kumar, 2004).

Pentingnya Infrastruktur TI juga dialami untuk industri kesehatan. IT di industri kesehatan (Healthcare Information Technologies/HIT) merupakan enablers untuk meningkatkan keselamatan pasien, mengurangi adanya medical errors, dan meningkatkan kepuasan pasien (Gardner, Boyer, \& Gray, 2015; Institute of Medicine, 2012). Tanpa adanya ketersediaan informasi yang baik, promosi atau Kesimpulan dari penelitian (Chaudry, et al., 2006), menyatakan HIT memberikan efektifitas dan efisiensi.

Di Indonesia, standart setiap rumah sakit dinilai oleh Komisi Akreditasi Rumah Sakit (KARS). Setiap rumah sakit memiliki nilai akreditasnya masing-masing. Di Indonesia, masih belum ada acuan pengembangan infrastruktur TI. Menurut (Bittman, 2004), Maturity model dapat digunakan untuk melakukan pengukuran dan guidelines pengembangan infrastruktur TI.

\footnotetext{
${ }^{1}$ Magister Teknik Informatika, Universitas Atma Jaya Yogyakarta

${ }^{2}$ Magister Teknik Informatika, Universitas Atma Jaya Yogyakarta

${ }^{3}$ Magister Teknik Informatika, Universitas Atma Jaya Yogyakarta
} 
Maturity model merupakan deskripsi sebuah proses evolusi dari sebuah entitas dalam sebuah kurun waktu, dimana entitas dapat berupa sebuah fungsi atau area (Tapia \& Guadalupe, 2009; Haris, 2010). Maturity model membantu perusahaan dalam melakukan perubahan atau pengembangan pada proses fungsional perusahaan, menentukan target-target pengembangan dan prioritas, memberikan guidance untuk melakukan kontrol kualitas, dan menyediakan benchmark untuk mengukur proses yang ada saat ini (Gomes, Romano, \& Caldeira, 2015).

Dengan melihat pentingnya Infrastruktur TI di industri kesehatan, diperlukan sebuah framework untuk membantu proses evaluasi dan pengembangan infrastruktur TI. Framework tersebut adalah maturity model dengan area pengukuran infrastruktur TI.

\section{Tinjauan Pustaka}

\subsection{Model Kematangan}

Pada tahun 1986, Software Engineering Institute (SEI $\left.{ }^{\mathrm{TM}}\right)$ di Carnegie Mellon University, dengan dibantu MITRE Corporation, mulai membuat sebuah framework pengukur tingkat kematangan untuk meningkatkan software process (Paulk M. , 2009; Humphrey, Three Process Perspectives: Organizations, Teams, and People, 2002). Berdasarkan penggunaan software process maturity framework dan kuestioner untuk melakukan analisa problem (Humphrey, Characterizing the software process: a maturity framework, 1988) dan meningkatkan proses (Humphrey \& Sweet, A Method for assessing the software engineering capability of contractors: preliminary version, 1987), $\mathrm{SEI}^{\mathrm{TM}}$ menyenamainya sebagai Capability Maturity Model for Software (Software CMM) (Paulk M. , 2009).

CMM version 1.0 dipublikasi pada tahun 1991 (Webber, Paulk, Wise, \& Withey, 1991). Sedangkan CMM versi 1.1 dipublikasi pada tahun 1993 (Paulk, Curtis, Chrissis, \& Weber, 1993; Paulk, Webber, Gracia, Chrissis, \& Bush, 1993). Kekurangan pada CMM versi 1.1 adalah CMM masih belum dapat digunakan sebagai silver bullet (sarana praktis) dan masih belum mencakup semua permasalahan yang penting untuk mencapai proyek yang sukses (Paulk, Curtis, Chrissis, \& Weber, 1993), seperti belum memberikan saran mengenai pengukuran kompetensi sumber daya manusia (Paulk, Webber, Gracia, Chrissis, \& Bush, 1993).

Software CMM menjadi dasar bagi banyak standarisasi dan frameworks, seperti People CMM (Curtis, Hefley, \& Miller, 2009), System Engineering CMM (Bate, Kuhn, Curt, Armitage, \& Clark, 1995), dan System Security Engineering CMM (Hefner, 1997). CMM menjadi dasar pembuatan CMM Integration ${ }^{T M}$ (CMMI), dimana CMMI mengintegrasikan antara system engineering, software engineering, dan integrated proses serta product development pada 1 model framework (Paulk M. , 2009; Crissis, Konrad, \& Shrum, 2003).

Kebanyakan frameworks yang menggunakan kerangka berpikir evolusi, seperti maturity model merupakan pengembangan dari CMM (Tapia \& Guadalupe, 2009; Haris, 2010). Maturity model merupakan framework yang mendeskripsikan evolusi dari sebuah entitas dalam rentang waktu tertentu, dan entitas dapat berupa bagian fungsional sebuah perusahan (Tapia \& Guadalupe, 2009). Frameworks tingkat kematangan memiliki kesamaan, yaitu selalu memiliki sebuah tingkatan kematangan atau maturity levels, dan karakter dari masing-masing tingkat (HüNer, Ofner, \& Otto, 2009; Haris, 2010).

Fokus dari CMMI adalah product engineering dan services engineering (Ahern, Clouse, $\&$ Turner, 2004), tetapi CMMI dapat digunakan untuk fokus area yang lain dalam memberikan support pada enterprise-wide concept (Constantinescu \& Iacob, 2007). Sama seperti CMMI, MM memiliki sebuah fokus area yang di sebut dengan entitas (Tapia \& Guadalupe, 2009).

\subsection{Infrastruktur TI}

Infrastruktur atau infrastructure adalah sebuah dasar layanan dan sistem, seperti transportasi, yang digunakan oleh negara atau perusahaan untuk dapat bekerja (Cambridge, 2016; Dictionary.com). Istilah infrastruktur memiliki banyak penggunaan sesuai dengan konteks, seperti green infrastructure (Tzoulas, et al., 2007), IT Infrastructure (Byrd \& Turner, 2000), dan lain sebagainya. Dalam penelitian ini, infrastruktur TI didefinisikan terdiri dari 2 aspek, yaitu aspek teknikal dan human aspect (Weill \& Vitale, What IT Infrastructure Capabilities are Needed to Implement E-Business Models, 2002). 


\subsection{Standarisasi Rumah Sakit}

Di Indonesia, standarisasi rumah sakit dikelola oleh Komisi Akreditasi Rumah Sakit atau KARS (Komisi Akreditasi Rumah Sakit, 2012). Tujuan melakukan standar akreditasi untuk rumah sakit adalah untuk meningkatkan mutu pelayanan rumah sakit, meningkatkan keselamatan pasien rumah sakit, meningkatkan perlindungan bagi pasien, masyarakat, sumber daya manusia rumah sakit, dan mendukung program pemerintah dibidang kesehatan (RS Jiwa Grhasia, 2014; Komisi Akreditasi Rumah Sakit, 2012).

Dalam menentukan akreditas, KARS menggunakan 22 kategori penilaian. Dari 22 kategori tersebut, dikelompokkan kedalam 4 sub-bagian besar (Komisi Akreditasi Rumah Sakit, 2012). Standarisasi RS di Indonesia belum ada yang mengatur infrastruktur TI.

\subsection{Model Kematangan}

Berikut ini beberapa penelitian terkait model kematangan dengan key-area infrastruktur TI, antara lain Gartner Infrastructure Maturity Model (Bittman, 2004), NHS Infrastructure Maturity Model (NHS, 2015; NHS PSPG, 2015), dan IT Infrastructure Maturity Model (Haris, 2010).

Gartner infrastructure maturity model (GIMM) memiliki tujuan untuk melakukan evaluasi dan membuat strategic plan untuk meningkatkan agility (kemampuan perusahaan melakukan sebuah perubahan dengan cepat) (Bittman, 2004). GIMM hanya mencakup area teknis saja, dan tidak mencakup area human IT infrastructure (Bittman, 2004; Haris, 2010).

NHS infrastructure maturity model atau NIMM ${ }^{\mathrm{TM}}$ di publikasikan oleh NHS Technology Office dan beberapa NHS IT Organization di United Kingdom (NHS, 2015; NHS PSPG, 2015). Pada saat melakukan pembuatan NIMM, anggota tim NHS berkolaborasi dengan Atos Healthcare, yang merupakan sebuah perusahaan konsultan (NHS, 2015). Berbeda dengan GIMM, NIMM ${ }^{\mathrm{TM}}$ sudah mencakup aspek teknis dan non-teknis (human IT infrastructure) (Savvides, 2009; Haris, 2010).

Penelitian yang dilakukan oleh (Haris, 2010) memberikan gambaran sebuah bagaimana maturity model dibuat untuk keperluan mengukur tingkat kematangan infrastruktur TI di sebuah perusahaan. Infrastruktur TI diukur dengan tujuan mencapai real-time infrastruktur TI. Kasus yang digunakan dalam penelitian ini adalah Deustche Telekom AG, perusahaan telekomunikasi di German. Model kematangan pada penelitian ini dihasilkan dengan cara menggabungkan kombinasi antara NIMM $^{\mathrm{TM}}$ dan GIMM. Kedua metode tersebut dikombinasikan berdasarkan 6 kriteria, yaitu knowledge management, price scheme, technical \& human IT infrastructure, technology-independent, real-time operations, dan agility. Kriteria tersebut dihasilkan berdasarkan kebutuhan dan tujuan dari model kematangan dibentuk.

Berdasarkan hasil studi literatur, di negara Amerika dan Inggris sudah memiliki metode pengukuran tingkat kematangan infrastruktur TI. Sedangkan di Indonesia masih belum ada metode untuk mengukur tingkat kematangan infrastruktur TI, khususnya pada infrastruktur TI di rumah sakit. Sehingga penulis mengusulkan melakukan adaptasi model pengukur tingkat kematangan infrastruktur TI untuk obyek penelitian rumah sakit. Alat pengukur tingkat kematangan yang dipilih untuk diadopsi adalah NHS infrastructure maturity model atau $\mathrm{NIMM}^{\mathrm{TM}}$, karena $\mathrm{NIMM}^{\mathrm{TM}}$ memang dibentuk untuk mengukur tingkat kematangan infrastruktur TI di rumah sakit (NHS PSPG, 2015; NHS, 2015).

Alasan lain dipilihnya NIMM $^{\mathrm{TM}}$ adalah karena GIMM \& ITI-MM memiliki fokus terhadap agility perusahaan (Bittman, 2004; Haris, 2010), sedangkan pada industri kesehatan, rumah sakit, agility tidak menjadi fokus utama. Fokus utama sistem informasi rumah sakit adalah ketersediaan layanan 24/7, penghematan biaya, konsistensi data, knowledge management, dan lain-lain.

Berdasarkan beberapa penelitian terdahulu (Tapia \& Guadalupe, 2009; NHS PSPG, 2015), dalam menggunakan maturity model diperlukan penyesuaian terkait kategori dan kriteria yang sesuai dengan prioritas perusahaan sebelum dapat digunakan untuk melakukan evaluasi tingkat kematangan. Metode ini juga dilakukan oleh (Haris, 2010), dimana dalam penelitiannya 
dilakukan sebuah proses studi pendahuluan terhadap obyek penelitian. Penyesuaian tersebut juga dapat memberikan perubahan pada jumlah tingkatan level kematangan.

\section{Landasan Teori}

Infrastruktur TI adalah fondasi dari IT Capability dalam sebuah perusahaan dalam bentuk layanan berbasis TI yang reliable (Haris, 2010; Broadbent, Weill, \& Neo, 1999). Infrastruktur TI terdiri dari 2 aspek, yaitu aspek human IT infrastructure dan technocal IT infrastructure (Broadbent, Weill, \& Neo, 1999). Aspek teknikal terdiri dari aplikasi, data dan technology configuration. Sedangkan aspek human terdiri dari pengetahuan dan capabilities untuk mengelola sumberdaya TI di perusahaan (Haris, 2010).

Human IT infrastructure meliputi semua hal yang terdapat pada sumber daya manusia, meliputi pengetahuan, pengalaman, kompetensi, komitmen, nilai dan norma dari setiap anggota tim TI (Henderson \& Venkatraman, 1999). Human IT infrastructure merupakan faktor penting karena setiap layanan TI bergantung kepada kemampuan teknikal seseorang dalam mengelola teknologi yang digunakan dalam setiap layanan TI.

Sedangkan technical IT infrastructure merupakan enabler untuk shared IT capabilities dalam sebuah proses bisnis (Byrd \& Turner, 2000). Technical IT infrastructure meliputi platform technology (hardware dan sistem operasi), network dan teknologi komunikasi, data, dan core software application.

Model kematangan atau maturity model merupakan sebuah metode atau framework untuk melakukan pengukuran tingkat kematangan dan blueprint untuk melakukan pengembangan suatu entitas dalam perusahaan (Bruin, Freeze, Kalkarni, \& Rosemann, 2005; Tapia \& Guadalupe, 2009). Maturity model mencerminkan evolusi sebuah entitas secara terus menerus (Tapia \& Guadalupe, 2009). Entitas disini adalah area atau fungsi di dalam sebuah organisasi. Berdasarkan maturity assessments, sebuah organisasi dapat mengetahui area mana yang belum dikelola dan didokumentasikan dengan baik.

NHS Infrastructure maturity model $\left(\mathrm{NIMM}^{\mathrm{TM}}\right.$ ) dibuat oleh NHS Technology Office dan beberapa NHS IT Organization di United Kingdom (Savvides A. , 2009; NHS PSPG, 2015). Pada saat melakukan pembuatan NIMM, anggota tim NHS berkolaborasi dengan Atos Healthcare, yang merupakan perusahaan konsultan. NIMM $^{\mathrm{TM}}$ melakukan assessment terhadap aspek teknis dan non-teknis (bisnis) (NHS PSPG, 2015). Aspek non-teknis pada NHS adalah business alignment, dengan 6 kategori dan aspek teknis mencakup 7 kategori. Tingkat kematatangan NIMM ${ }^{\mathrm{TM}}$ adalah 5 tingkat, yaitu level 1 (basic), level 2 (Controlled), level 3 (Standardised), level 4 (Optimised), dan level 5 (Innovative).

\section{Metode Penelitian}

Penelitian ini dilakukan dengan 4 tahap, yaitu studi pendahuluan (1), adaptasi model kematangan (2), dan validasi model kematangan (3).

Tahap pendahuluan (1), ini bertujuan untuk menghasilkan dasar-dasar yang digunakan untuk memahami model kematangan dan cara melakukan evaluasi menggunakan model kematangan. Studi pendahuluan dilakukan dengan 2 cara, yaitu studi literatur dan observasi awal.

Tahap adaptasi model kematangan (2) adalah proses adaptasi dari model kematangan yang dipilih, dalam hal ini NIMM ${ }^{\mathrm{TM}}$ menjadi maturity model yang diusulkan. Pada penelitian ini dibatasi yang diadaptasi adalah jumlah key capabilities yang diperlukan untuk rumah sakit di Indonesia. Pada penelitian, proses adaptasi dilakukan dengan cara mengumpulkan informasi kondisi aktual dari obyek penelitian, RS XYZ. Dari informasi awal tersebut, dilakukan penyesuaian terhadap kategori, key capabilities dan level dari model kematangan NIMM $^{\mathrm{TM}}$.

Proses validasi maturity model (3) adalah proses melakukan validasi komponen kategori, key capabilities, dan tingkat kematangan yang ada di usulan model kematangan. Proses validasi dilakukan dengan cara melakukan interview dan questioner tertutup dengan anggota divisi TI RS XYZ. 


\section{Hasil dan Pembahasan}

\subsection{Perubahan dari model kematangan NIMM ${ }^{\mathrm{TM}}$}

Perubahan dari model kematangan $\mathrm{NIMM}^{\mathrm{TM}}$, Berdasarkan hasil adaptasi model kematangan terdapat perubahan jumlah kategori dari yang sebelumnya berjumlah 13, menjadi 11 kategori. Ada 2 kategori yang tidak sesuai dengan kebutuhan dan kondisi di RS XYZ sehingga dihapuskan dari model hasil adaptasi.

Daftar kategori yang dihapus dari model kematangan hasil adaptasi dapat dilihat pada

Tabel 2. Daftar kategori yang dihapus dibawah ini.

Tabel 2. Daftar kategori yang dihapus

\begin{tabular}{|c|l|l|}
\hline No & \multicolumn{1}{|c|}{ Kategori } & \multicolumn{1}{c|}{ Alasan } \\
\hline 1 & Procurement & $\begin{array}{l}\text { Karena proses procurement pada divisi TI, dikelola oleh divisi } \\
\text { Pembelian. Dalam proses procurement, divisi TI hanya bertugas } \\
\text { memberikan rekomendasi spesifikasi. Sedangkan pemilihan harga, } \\
\text { vendor, dan semua hal yang berhubungan dengan proses pembelian } \\
\text { diserahkan kepada divisi Pembelian. } \\
\text { Sehingga tidak relevan melakukan pengukuran tingkat kematangan } \\
\text { untuk kategori procurement di RS XYZ. }\end{array}$ \\
\hline 2 & Financial management & $\begin{array}{l}\text { Karena proses procurement dimulai ketika divisi "peminta" } \\
\text { melakukan permintaan pembelian hardware/software ke pimpinan } \\
\text { RS XYZ, kemudian apabila permintaan tersebut di setujui oleh } \\
\text { pimpinan RS XYZ, maka akan muncul perintah untuk divisi TI } \\
\text { memberikan rekomendasi. } \\
\text { Dengan proses procurement seperti ini, tidak relevan melakukan } \\
\text { pengukuran tingkat kematangan untuk kategori financial } \\
\text { management, karena yang melakukan pengukuran investasi adalah } \\
\text { divisi "peminta" dan pimpinan. }\end{array}$ \\
\hline
\end{tabular}

Berdasarkan hasil proses adaptasi model kematangan, terdapat beberapa capabilities/komponen evaluasi yang dihapus dari $\mathrm{NIMM}^{\mathrm{TM}}$. $\mathrm{NIMM}^{\mathrm{TM}}$ memiliki 76 key capabilities, sedangkan model hasil adaptasi memiliki 60 key capabilities. Terdapat 16 key capabilities yang dianggap tidak relevan dengan kondisi di RS XYZ. Daftar key capabilities yang dihapus dari model kematangan hasil adaptasi dapat dilihat pada tabel Tabel 3. Daftar key capabilities yang dihapus dibawah ini.

Tabel 3. Daftar key capabilities yang dihapus

\begin{tabular}{|c|c|c|c|}
\hline No & Kategori & Key Capabilities & Alasan \\
\hline 1 & Procurement & $\begin{array}{l}\text { Seluruh key capabilities } \\
\text { (3 key capabilities) }\end{array}$ & $\begin{array}{l}\text { Karena proses procurement pada divisi TI, } \\
\text { dikelola oleh divisi Pembelian. Dalam proses } \\
\text { procurement, divisi TI hanya bertugas } \\
\text { memberikan rekomendasi spesifikasi. } \\
\text { Sedangkan pemilihan harga, vendor, dan } \\
\text { semua hal yang berhubungan dengan proses } \\
\text { pembelian diserahkan kepada divisi } \\
\text { Pembelian. }\end{array}$ \\
\hline 2 & $\begin{array}{l}\text { Financial } \\
\text { management }\end{array}$ & $\begin{array}{l}\text { Seluruh key capabilities } \\
\text { (3 key capabilities) }\end{array}$ & $\begin{array}{l}\text { Karena proses procurement dimulai ketika } \\
\text { divisi "peminta" melakukan permintaan } \\
\text { pembelian hardware/software ke pimpinan RS } \\
\text { XYZ, kemudian apabila permintaan tersebut di } \\
\text { setujui oleh pimpinan RS XYZ, maka akan } \\
\text { muncul perintah untuk divisi TI memberikan } \\
\text { rekomendasi. }\end{array}$ \\
\hline 3 & $\begin{array}{l}\text { IT Security \& } \\
\text { Information } \\
\text { Governance }\end{array}$ & Directory Services & $\begin{array}{l}\text { Karena RS XYZ pernah menggunakan } \\
\text { directory services, tetapi terdapat beberapa } \\
\text { permasalahan pada saat penggunaan directory } \\
\text { services sehingga tidak lagi digunakan. }\end{array}$ \\
\hline
\end{tabular}




\begin{tabular}{|c|c|c|c|}
\hline No & Kategori & Key Capabilities & Alasan \\
\hline 4 & $\begin{array}{l}\text { Common } \\
\text { Application } \\
\text { Services }\end{array}$ & Callendar \& Scheduling & $\begin{array}{l}\text { Di RS XYZ tidak menggunakan callendar \& } \\
\text { scheduling, masing-masing memiliki jadwal } \\
\text { sendiri }\end{array}$ \\
\hline 5 & $\begin{array}{l}\text { Common } \\
\text { Application } \\
\text { Services }\end{array}$ & Unified Communication & $\begin{array}{l}\text { Di RS XYZ tidak menggunakan unified } \\
\text { communication, masing-masing } \\
\text { memiliki group IM sendiri }\end{array}$ \\
\hline 6 & $\begin{array}{l}\text { Operating } \\
\text { Systems }\end{array}$ & $\begin{array}{l}\text { PC Application } \\
\text { Virtualization }\end{array}$ & $\begin{array}{l}\text { Karena setiap PC didedikasikan untuk } 1 \text { fungsi } \\
\text { (misal: PC untuk SIM RS Laboratorium, tidak } \\
\text { dapat digunakan untuk keperluan lain), } \\
\text { sehingga tidak diperlukan virtualisasi. }\end{array}$ \\
\hline 7 & $\begin{array}{l}\text { Operating } \\
\text { Systems }\end{array}$ & $\begin{array}{l}\text { Operating System } \\
\text { Virtualization }\end{array}$ & $\begin{array}{l}\text { Karena setiap PC didedikasikan untuk } 1 \text { fungsi } \\
\text { (misal: PC untuk SIM RS Laboratorium, tidak } \\
\text { dapat digunakan untuk keperluan lain), } \\
\text { sehingga tidak diperlukan virtualisasi. }\end{array}$ \\
\hline 8 & $\begin{array}{l}\text { Infrastructure } \\
\text { Hardware } \\
\text { Platforms }\end{array}$ & Server Consolidation & $\begin{array}{l}\text { Karena RS XYZ menggunakan } 1 \text { hardware } \\
\text { server untuk melayani request sejenis (1 } \\
\text { aplikasi), dan spesifikasi hardware server } \\
\text { disesuai kebutuhan } 1 \text { aplikasi tersebut untuk } \\
\text { jangka waktu pemakaian } 3 \text { tahun.. }\end{array}$ \\
\hline 9 & $\begin{array}{l}\text { Infrastructure } \\
\text { Hardware } \\
\text { Platforms }\end{array}$ & Server Virtualization & $\begin{array}{l}\text { Karena RS XYZ menggunakan } 1 \text { hardware } \\
\text { server untuk melayani request sejenis (1 } \\
\text { aplikasi), dan spesifikasi hardware server } \\
\text { disesuai kebutuhan } 1 \text { aplikasi tersebut untuk } \\
\text { jangka waktu pemakaian } 3 \text { tahun. }\end{array}$ \\
\hline 7 & $\begin{array}{l}\text { Infrastructure } \\
\text { Hardware } \\
\text { Platforms }\end{array}$ & Storage Virtualization & $\begin{array}{l}\text { Karena RS XYS menggunakan } 1 \text { hardware } \\
\text { server untuk melayani request sejenis (1 } \\
\text { aplikasi), kebutuhan storage disesuaikan untuk } \\
1 \text { aplikasi tersebut untuk jangka waktu } \\
\text { pemakaian } 3 \text { tahun.. }\end{array}$ \\
\hline 8 & $\begin{array}{l}\text { Business } \\
\text { alignment }\end{array}$ & Stakeholder management & $\begin{array}{l}\text { Karena divisi TI RS XYZ berada di bawah } \\
\text { divisi keuangan, dan pengelolaan stakeholder } \\
\text { dilakukan pada tingkat direktur. }\end{array}$ \\
\hline 9 & $\begin{array}{l}\text { Infrastructure } \\
\text { Governance }\end{array}$ & $\begin{array}{l}\text { Product \& service } \\
\text { catalogue }\end{array}$ & $\begin{array}{l}\text { Karena divisi TI tidak mengelola daftar produk } \\
\text { dan servis yang dimiliki. Dokumentasi } \\
\text { kepemilikan layanan hanya sebatas spesifikasi } \\
\text { produk untuk internal divisi TI } \\
\text { Masing-masing divisi hanya menggunakan } 1 \\
\text { aplikasi saja. }\end{array}$ \\
\hline
\end{tabular}

\subsection{Kategori model hasil adaptasi}

Model kematangan hasil adaptasi memiliki 11 kategori dengan 60 key capabilities di dalamnya. Daftar kategori dan key capabilities yang ada di model kematangan dapat dilihat pada Tabel 4. Daftar kategori model kematangan hasil adaptasi dibawah ini.

Tabel 4. Daftar kategori model kematangan hasil adaptasi

\begin{tabular}{|c|l|l|}
\hline No & \multicolumn{1}{|c|}{ Kategori } & Deskripsi \\
\hline 1 & Infrastructure Pattern \& & - Standarisasi atau prosedur atau best practices untuk membuat \\
& Practices & dan memberikan layanan infrastruktur TI. \\
& & - Merupakan dasar untuk untuk melakukan untuk standarisasi \\
& & pada bagian lainnya dan mengoptimalkan proses penyediaan \\
& & layanan infrastruktur TI. \\
& & - Key Capabilities: 1.1 Availability Management, 1.2 Change \\
& & Management, 1.3 Configuration Management, 1.4 Release \\
& & Management, 1.5 Problem Management, 1.6 Incident \\
& & Management, 1.7 Service Desk, 1.8 Capacity Management, \\
& & I.9 IT Service Continuity Management, 1.10 Service \\
\hline
\end{tabular}




\begin{tabular}{|c|c|c|}
\hline No & Kategori & Deskripsi \\
\hline & & $\begin{array}{l}\text { Monitoring, 1.11 End User Provisioning, 1.12 Software Asset } \\
\text { Management, 1.13 Patch Management, 1.14 Testing }\end{array}$ \\
\hline 2 & $\begin{array}{l}\text { IT Security \& Information } \\
\text { Governance }\end{array}$ & $\begin{array}{l}\text { - Penggunaan teknologi yang berhubungan dengan masalah } \\
\text { security dan akses kontrol untuk menjaga aspek sistem dan } \\
\text { informasi. } \\
\text { - Mencakup security di area jaringan, hardware, sistem opera, } \\
\text { dan aplikasi yang digunakan. } \\
\text { - Key Capabilities: 2.1 LAN Security Policy, } 2.2 \text { WAN \& } \\
\text { Remote Access Security Policy, 2.4 Single Sign-on, } 2.5 \\
\text { Identity Management, 2.6 Data Security, 2.7 End Point } \\
\text { Security, 2.8 Antivitrus \& Malware Protection }\end{array}$ \\
\hline 3 & $\begin{array}{l}\text { Common Application \& } \\
\text { Services }\end{array}$ & $\begin{array}{l}\text { - Sebuah layanan aplikasi yang dapat di seluruh perusahaan. } \\
\text { - Pengguna dapat berupa manusia/end-user atau komponen } \\
\text { infrastruktur lain. } \\
\text { - Key Capabilities: } 3.1 \quad \text { Electronic Messaging, } 3.2 \\
\text { Collaboration, } 3.3 \text { Knowledge Management, 3.4 Remote } \\
\text { User Access, } 3.5 \text { Electronic Software Distribution, } 3.6 \\
\text { Enterprise Content Management, } 3.7 \text { Enterprise Search, } 3.8 \\
\text { File \& Print Services }\end{array}$ \\
\hline 4 & End User Device & $\begin{array}{l}\text { - Hardware atau perangkat yang digunakan oleh end-users } \\
\text { untuk menggunakan layanan dari infrastruktur TI. } \\
\text { - Mencakup tablet PC, PDA, dan perangkat lainnya. } \\
\text { - Key Capabilities: 4.1 Bring Your Own Device, 4.2 Primary } \\
\text { Care Telephony Infrastructure and Services, 4.3 Tablet } \\
\text { Device }\end{array}$ \\
\hline 5 & Operating System & $\begin{array}{l}\text { - Pengaturan Software yang bertugas sebagai sistem operasi } \\
\text { komputer. } \\
\text { - Mencakup sistem operasi server, sistem operasi client, dan } \\
\text { sistem operasi perangkat lainnya. } \\
\text { - Key Capabilities: } 5.1 \text { PC Operating System Standarisation, } \\
\text { 5.2 Operating System Configuration Management, } 5.3 \text { Server } \\
\text { Provisioning }\end{array}$ \\
\hline 6 & $\begin{array}{l}\text { Infrastructure Hardware } \\
\text { Platform }\end{array}$ & $\begin{array}{l}\text { - Pengaturan Hardware yang digunakan secara bersama-sama } \\
\text { untuk keperluan infrastruktur TI. } \\
\text { - Mencakup pengelolaan configuration management, } \\
\text { penggunaan daya listrik dan pendingin, shared hardware } \\
\text { seperti shared server dan shared storages. } \\
\text { - Key Capabilities: } 6.1 \text { Data Storage Management, 6.2 Power } \\
\text { \& Cooling Management, 6.3 Infrastructure Hardware } \\
\text { Configuration Management }\end{array}$ \\
\hline 7 & Network Device \& Services & $\begin{array}{l}\text { - Mencakup hardware dan software yang bertugas } \\
\text { memberikan layanan jaringan. } \\
\text { - Key Capabilities: } 7.1 \text { Wireless LAN \& PAN, 7.2 Fixed LAN, } \\
\text { 7.3 Local Network Services, 7.4 Network Cabling, 7.5 LAN } \\
\text { Configuration Management, 7.6 Network Services Security }\end{array}$ \\
\hline 8 & Business Alignment & $\begin{array}{l}\text { - Melihat kondisi kesesuaian kebutuhan bisnis dengan layanan } \\
\text { infrastruktur TI. } \\
\text { - Mengukur kesesuaian kebutuhan bisnis dengan infrastruktur } \\
\text { TI, dan bagaimana prosesnya di kelola. } \\
\text { - Key Capabilities: } 8.2 \text { IT Infrastructure Risk Management, } \\
\text { 8.3 IT Business Strategy Aligment }\end{array}$ \\
\hline 9 & Infrastructure Governance & $\begin{array}{l}\text { - Bagaimana infrastruktur TI dikelola? Apakah ada } \\
\text { penggunaan frameworks (COBIT) untuk mengelola? } \\
\text { - Key Capabilities: 9.1 IT Infrastructure Architecture \& } \\
\text { Governance, 9.2 IT Infrastructure Strategy \& Planning, 9.3 } \\
\text { Document Collaboration \& Knowledge Management } \\
\text { Strategy, 9.4 IT Project / Program Management }\end{array}$ \\
\hline
\end{tabular}




\begin{tabular}{|c|l|l|}
\hline No & Kategori & Deskripsi \\
\hline $\mathbf{1 0}$ & People \& Skills & - Apakah skills yang dimiliki oleh anggota TI, sudah sesuai \\
& & dengan bidang-nya masing-masing? \\
& & - Apakah proses delivery layanan infrastruktur TI sudah \\
& & dilakukan secara efektif? \\
& & - Key Capabilities: 10.1 IT Staff Career Pathways \& \\
& & Development, 10.2 IT Staff Performance Management, 10.3 \\
& & End User Training, 10.4 IT Staff Development Training, 10.5 \\
& & IT Staff Attraction, Motivation, \& Retention \\
\hline $\mathbf{1 1}$ & Principles, Standards, & - Prinsip, standards, prosedur, dan guidelines dalam \\
& Procedures, and Guidelines & memberikan layanan infrastruktur TI. \\
& & - Key Capabilities: 11.1 Infrastructure Principles, 11.2 \\
& & Infrastructure Standards, 11.3 Infrastructure Procedures, \\
& & 11.4 Infrastructure Guidelines, 11.5 Green IT \\
\hline
\end{tabular}

Model hasil adaptasi menggunakan 5 perspektif untuk masing-masing key capabilities. 5 perspektif tersebut ialah:

1. Process Perspective fokus kepada authoritative, automation, quality \& consistency, best practice, speed, dan efficiency.

2. Organisation \& People Perspective fokus kepada kualitas data yang disediakan, accessibility \& user experience, convenience, functionality provided by capability, skills \& organisation to deliver \& manage the capability.

3. Technology Perspective fokus kepada dependable, manageable, scalable, robust, dan standards based.

4. IT Security \& Information Governance Perspective fokus kepada security, IG compliance, standards adherence, trustworthy, dan auditable.

5. Strategy Alignment \& Business Value Perspective fokus kepada kesesuaian bisnis dan kebutuhan user, kegunaan dan peningkatan nilai fungsi.

Dari masing-masing perspektif, model kematangan hasil adaptasi memiliki 1 atau lebih. Jumlah KPI yang ada pada model kematangan adalah 432 KPI, dengan Process Perspective memiliki 106 KPI, Organisation \& People Perspective memiliki 97 KPI, Technology Perspective memiliki 103 KPI, IT Security \& Information Governance Perspective memiliki 83 KPI, dan Strategy Alignment \& Business Value Perspective memiliki 85 KPI. Masingmasing KPI memiliki format seperti tabel

Tabel 5. Format KPI

\begin{tabular}{|c|c|}
\hline \multicolumn{2}{|l|}{ KPI Description } \\
\hline \multicolumn{2}{|c|}{ [Deskripsi singkat dari KPI untuk masing-masing perspektif, berupa sebuah pertanyaan] } \\
\hline Metric & NIMM Level \\
\hline $\begin{array}{l}\text { [Deskripsi untuk level 1] } \\
\text { - } \quad \text { Disjointed, manual infrastructure } \\
\text { - } \quad \text { Knowledge not shared } \\
\text { - } \quad \text { Unpredive and ad-hoc } \\
\text { - User driven "who shouts loudest" } \\
\text { - Avoid downtime }\end{array}$ & $\begin{array}{c}\text { Basic } \\
1\end{array}$ \\
\hline $\begin{array}{ll}\text { [Deskripsi untuk level 2] } \\
\text { - } & \text { Co-ordinated manual infrastructure } \\
\text { - } & \text { Knowledge shared but in silos } \\
\text { - } & \text { Mainly reactive with some planning } \\
\text { - } & \text { Services are managed and some predictability }\end{array}$ & $\begin{array}{c}\text { Controlled } \\
2\end{array}$ \\
\hline
\end{tabular}




\begin{tabular}{|c|c|}
\hline KPI Description & \\
\hline [Deskripsi singkat dari KPI untuk masing-masing perspektif, berupa sebuah $p$ & nyaan] \\
\hline Metric & NIMM Level \\
\hline $\begin{array}{l}\text { - } \quad \text { Problem driven } \\
\text { - Avoid downtime }\end{array}$ & \\
\hline $\begin{array}{l}\text { [Deskripsi untuk level 3] } \\
\text { - } \quad \text { Standardised Infrastructure } \\
\text { - } \quad \text { Individual Level collaboration and knowledge sharing } \\
\text { - } \quad \text { Reactive \& becoming proactive } \\
\text { - } \quad \text { Request driven } \\
\text { - Standards \& Best Practice }\end{array}$ & $\begin{array}{c}\text { Standardised } \\
3\end{array}$ \\
\hline $\begin{array}{l}\text { [Deskripsi untuk level 4] } \\
\text { - Consolidated and virtualised infrastructure } \\
\text { - Team level knowledge sharing and collaboration } \\
\text { - } \text { Proactive and accountable } \\
\text { - Continuous Service Improvement } \\
\text { - Service driven } \\
\text { - Efficiency }\end{array}$ & $\begin{array}{c}\text { Optimised } \\
4\end{array}$ \\
\hline $\begin{array}{l}\text { [Deskripsi untuk level 5] } \\
\text { - IT \& Business stakeholders work in partnership } \\
\text { - Enterprise level knowledge sharing and collaboration } \\
\text { - Strategic asset } \\
\text { - Drives service Innovation } \\
\text { - Value driven } \\
\text { - Catalyst for Innovation }\end{array}$ & $\begin{array}{c}\text { Innovative } \\
5\end{array}$ \\
\hline Self Assessed NIMM Level & \\
\hline
\end{tabular}

\section{Kesimpulan}

Hasil dari penelitian ini telah mampu mencapai tujuan penelitian untuk mengadaptasi model kematangan NHS Infrastructure Maturity Model (NIMM $\left.{ }^{\mathrm{TM}}\right)$ sesuai dengan kebutuhan dari rumah sakit di yogyakarta, dalam kasus ini adalah RS XYZ.

Model hasil adaptasi memiliki 11 kategori dan terdiri dari 60 key capabilities dari $\mathrm{NIMM}^{\mathrm{TM}}$. Kategori yang ada pada model hasil adaptasi adalah Infrastructure pattern \& practices, IT security \& information governance, common application \& services, end user device, operating system, infrastructure hardware platform, network device \& services, business alignment, infrastructure governance, people \& skills, dan principles, standards, procedures, \& guidelines.

Model kematangan memiliki 5 perspektif untuk masing-masing key capabilities, yaitu process perspective, organisation \& people perspective, technology perspective, IT security \& information governance perspective, dan strategy alignment \& business value perspective. Dari masing-masing perspektif, model kematangan hasil adaptasi memiliki 1 atau lebih KPI. Total KPI yang ada di model kematangan hasil adaptasi adalah 432 KPI. 


\section{Daftar Pustaka}

IBM Institute. The IT Infrastructure Conversation. IBM Global Business Services. IBM.

IBM Institute. Continuing the IT infrastructure conversation. IBM Global Business Services. IBM.

Haris, F. (2010). IT Infrastructure Maturity Model - A Roadmap to Agile IT Infrastructure. Master Thesis, University of Twente, The Netherland.

Broadbent, M., Weill, P., \& Neo, B. (1999). Strategic context and patterns of IT Infrastructure capability. Journal of Strategic Information Systems , 8, 157-187.

Rossi, B. (2015, Januari 6). 2015's most critical information technology trends. Retrieved August 17, 2015, from Information Age: http://www.information-age.com/it-management/strategy-andinnovation/123458793/2015s-most-critical-information-technology-trends

Kumar, R. (2004). A Framework for Assessing the Business Value of Information Technology Infrastructure. Journal of Management Information Systems , 21 (2), 11-31.

Gardner, J., Boyer, K., \& Gray, J. (2015). Operational and strategic information processing: Complementing healthcare IT infrastructure. Journal of Operations Management , 33-34, 123-139.

Institute of Medicine. (2012). Health IT and Patient Safety: Building Safer Systems for Better Care (Final Book ed.). Washington, D.C.: The National Academies Press.

Chaudry, B., Wang, J., Wu, S., Maglione, M., Mojica, W., Roth, E., et al. (2006). Systematic review: Impact of health information technology on quality, efficiency and costs of medical care. Annals of Internal Medicine, $144,742-752$.

Cresswell, K., \& Sheikh, A. (2015). Health information technology in hospitals: current issues and future trends. Future Hospital Journal , 2 (1), 50-56.

Gomes, J., Romano, M., \& Caldeira, M. (2015). Linking Benefits to Maturity Models - ResearchGate. Retrieved August 18, 2015, from Research Gate: http://www.researchgate.net/publication/236577015 Linking Benefits to Maturity Models

Bittman, T. (2004). Gartner Introduces the Infrastructure Maturity Model. Publication, Gartner Inc.

Savvides, A. (2009). Your guide to the NHS Infrastructure Maturity Model. NHS.

NHS PSPG. (2015). Bundle: NHS Infrastructure Maturity Model. Retrieved September 2015, 28, from NHS PSPG: https://www.pspg.nhs.uk/home

NHS. (2015). NIMM Overview. Retrieved August 28, 2015, from Health \& Social Care Information Centre: http://systems.hscic.gov.uk/nimm/overview

Komisi Akreditasi Rumah Sakit. (2012). Instrumen Akreditasi Rumah Sakit Standar Akreditasi versi 2012. KARS, Jakarta.

Bruin, T. d., Freeze, R., Kalkarni, U., \& Rosemann, M. (2005). Understanding the Main Phases of Developing a Maturity Assessment Model. Australian Conference on Information Systems. Sydney.

Henderson, J., \& Venkatraman, N. (1999). Strategic Alignment: Leveraging information technology for transforming organizations. IBM System Journal , 38 (2\&3), 472-484.

Byrd, T. A., \& Turner, D. E. (2000). Measuring the Flexibility of Information Technology Infrastructure: Explanatory Analysis of a Construct. Journal of Management Information Systems , 17 (1), 167-208.

RS Jiwa Grhasia. (2014, 04 07). Akreditasi Rumah Sakit versi 2012. Retrieved 02 19, 2016, from RS Jiwa Grhasia: http:/grhasia.jogjaprov.go.id/index.php/artikel/umum/62-akreditasi-rumah-sakit-versi-2012

Humphrey, W. (2002). Three Process Perspectives: Organizations, Teams, and People. Annals of Software Engineering , 14 (1), 39-72.

Paulk, M. (2009). A history of the capability maturity model for software. ASQ Software Quality Professional , 12 (1), 5-19.

Humphrey, W. (1988). Characterizing the software process: a maturity framework. Software, 5 (2), 73-79.

Humphrey, W., \& Sweet, W. (1987). A Method for assessing the software engineering capability of contractors: preliminary version. CARNEGIE-MELLON UNIV PITTSBURGH PA SOFTWARE ENGINEERING INST. Pittsburg: Carnegie-Mellon University.

Paulk, M. C., Curtis, B., Chrissis, M. B., \& Weber, C. V. (1993). Capability Maturity Model for Software, Version 1.1. Carnegie Mellon University, Software Engineering Institute. Pittsburgh: Carnegie Mellon University.

Paulk, M., Webber, C., Gracia, S., Chrissis, M., \& Bush, M. (1993). Key Practices of the Capability Maturity Model Version 1.1. Carnagie Mellon University, Software Engineering Institute. Carnagie Mellon University.

Webber, C., Paulk, M., Wise, C., \& Withey, J. (1991). Key Practices of the Capability Maturity Model. Carnegie Mellon University, Software Engineering Institute. Pittsburgh: Carnegie Mellon University.

Curtis, B., Hefley, B., \& Miller, S. (2009). People Capability Maturity Model (P-CMM) Version 2.0. Carnegie Mellon University, Software Engineering Institute. Pittsburgh: Carnegie Mellon University.

Bate, R., Kuhn, D., Curt, W., Armitage, j., \& Clark, G. (1995). A Systems Engineering Capability Maturity Model, Version 1.1. Carnegie Mellon University, Software Engineering Institute. Pittsburgh: Carnegie Mellon University.

Hefner, R. (1997). Lessons learned with the systems security engineering capability maturity model. Proceedings of the 19th international conference on Software engineering (pp. 566-567). ACM.

Crissis, M., Konrad, M., \& Shrum, S. (2003). CMMI Guidlines for Process Integration and Product Improvement. Boston, MA, USA: Addison-Wesley Longman Publishing Co., Inc.

Constantinescu, R., \& Iacob, I. (2007). Capability Maturity Model Integration. Journal of Applied Quantitative Methods , 2 (1), 31-37. 
Ahern, D., Clouse, A., \& Turner, R. (2004). CMMI distilled: a practical introduction to integrated process improvement. Addison-Wesley Professional.

Cambridge. (2016). Cambridge Dictionaries Online. Retrieved Feb 21, 2016, from Cambridge Dictionaries Online: http://dictionary.cambridge.org/dictionary/english/infrastructure

Dictionary.com. (n.d.). Dictionary.com. Retrieved Feb 21, 2016, from http://dictionary.reference.com/browse/infrastructure

Tzoulas, K., Korpela, K., Venn, S., Pelkonen, V., Kaźmierczak, A., Niemela, J., et al. (2007). Promoting ecosystem and human health in urban areas using Green Infrastructure: A literature review. Landscape and Urban Planning , 81 (3), 167-178.

Tapia, S., \& Guadalupe, R. (2009). Assessing business-IT alignment in networked organizations. University of Twente.

HüNer, K. M., Ofner, M., \& Otto, B. (2009). Towards a maturity model for corporate data quality management. SAC '09 Proceedings of the 2009 ACM symposium on Applied Computing (pp. 231-238). New York: ACM.

Weill, P., \& Vitale, M. (2002). What IT Infrastructure Capabilities are Needed to Implement E-Business Models. MIS Quarterly Executives , 1 (1), pp. 17-34.

Laudon, K., \& Laudon, J. (2002). Management Information System (7th Edition ed.). (P. Hall, Ed.) New Jersey. 